\title{
Náboženské motivy v tvorbě Josefa Suka
}

\section{Religious Motifs in Josef Suk's Works}

\author{
Jan Charypar / jan.charypar@gmail.com
}

Department of Musicology, Faculty of Arts, Masaryk University, Brno, CZ

\begin{abstract}
This article deals with religious motifs in the works by the Czech composer Josef Suk. It focuses on Suk's personal and artistic relation to religion, on musical citations from sacred music in his works, and on his works which have topics closely related to religion. The findings give an image of the progress of the spiritual content of Suk's works during his lifetime.
\end{abstract}

\section{Keywords}

Josef Suk, Czech music, sacred music, Julius Zeyer, Otokar Březina, Saint Wenceslas Chorale 


\section{Sukův osobní a umělecký poměr k náboženství}

„Když s Bohem milým práci počínáme, pomoc Jeho a požehnání jistě dosáhneme. Také já dne 3. března r. 1882 čítaje 8 let stáři svého vzal jsem malinké housličky pod paždi, požehnal se svatým kř́žkem a ubiral se $k$ obydli p. Plachého, bych s pomoci boži počal na housličky hráti. Prosil jsem jej snažně, by mne jen malounko naučil hráti k svátku drahého tatícka."1 Takto si osmiletý Josef Suk zaznamenal do zápisníčku své první krůčky v hudbě. Vyrostl z kantorské tradice v katolické rodině křečovického řídícího učitele a regenschoriho Josefa Suka (18271913). S náboženským životem ve vsi byly proto těsně spjaty i zážitky, které v dětství formovaly jeho lásku k hudbě. Křečovický kůr patřil k místům, kde se poprvé uplatňoval jako malý houslista, jak o tom sám vyprávěl v projevu v Českých Budějovicích. ${ }^{2}$ Rodinná tradice pro něj do konce života znamenala mnoho z lidského i uměleckého hlediska: „[...] rodičům a rodnému kraji děkuji za to, že jsem se naučil rozuměti duši lidské a duši hudby. "

V Sukově osobní korespondenci můžeme nalézt dostatečné důkazy, že byl člověkem pevně zakotveným v křestanské víře. Nejde jen o běžný výskyt obratů jako „Bůh vás opatruj“ apod., ale také např. o dopisy skladateli Ladislavu Vycpálkovi ${ }^{4}$ a předsedkyni brněnského Sboru moravských učitelek Kristě Stejskalové, ${ }^{5}$ ve kterých Suk zřetelně projevil křestanské vyznání. Oba dopisy se týkají jeho vokálně-orchestrálního Epilogu, op. 37 (1920-33) a ještě se k nim vrátíme v pojednání o této skladbě. Dle dochované vzpomínky Suk údajně takto porovnal svou tvorbu s dílem Josefa Bohuslava Foerstera: „Já začínám každé své dílo od země, kde jsem se narodil, jdu výše, ke klasům, keřiom a potom k stromům a ještě výš a výš, až se povznesu k Bohu. Foerster jde opačnou cestou. "Je to jen nepřímý citát, pocházející ze vzpomínky blíže nejmenovaného J. K. z Chlumu u Sedlčan, kterou zařadil Josef Šach do své monografie Josef Suk: Vzpomínková mosaika. ${ }^{6}$ Nicméně pokud jí lze věřit, je to zajímavá charakteristika Sukova uměleckého vztahu k Bohu.

Navzdory svému křestanskému vyznání Suk nepatří k těm českým skladatelům, kteří se hojněji věnovali náboženské hudbě. Projdeme-li si v tematickém katalogu Sukových skladeb kromě dokončených děl též skladby nedokončené, můžeme shrnout výskyt náboženských motivů v jeho tvorbě takto: ${ }^{7}$ Jeho jedinou latinskou liturgickou skladbou je Mše $B$ dur, kterou zkomponoval ještě před studiem skladby na konzervatoři ve čtrnácti či patnácti letech (1888 nebo 1889, zdroje se liší; roku 1931 ji revidoval, posléze byla nazvána Křrečovická mše), cele na tradiční křestanský text jinak napsal jen skicu smíšeného sboru Hospodin jest můj pastýř (nedokončen, 1907). Na objednávku Julia Zeyera napsal hudbu k jeho náboženské legendě Pod jabloni, op. 20 (1901, roku 1911 z ní sestavil kon-

1 SVOBODOVÁ, Marie (ed.). Josef Suk: Dopisy nejbližším. Praha: Supraphon, 1976, s. 13.

2 KVĚT, Jan Miroslav (ed.). Živá slova Josefa Suka. Praha: Topičova edice, 1946, s. 110-111.

3 Ibid., s. 112.

4 VOJTĚŠKOVÁ, Jana (ed.). Josef Suk: Dopisy o životě hudebním i lidském. Praha: Editio Bärenreiter, 2005, s. 381-383.

5 Ibid., s. 306.

6 ŠACH, Josef. Josef Suk: Vzpomínková mosaika. Praha: A. Neubert, 1941, s. 13.

7 NOUZA, Zdeněk - NOVÝ, Miroslav. Josef Suk: Tematický katalog skladeb. Praha: Editio Bärenreiter, 2005. 
certní suitu). Z citací hudebních motivů lze zmínit Meditaci na staročeský chorál Svatý Václave, op. 35a (1914), možný vliv chorálu Ktož jsú boži bojovníci na hlavní téma symfonické básně Praga, op. 24 (1904) a citace základního čtyřtónového motivu Dvořákova Requiem (v symfonii Asrael, op. 27, 1906, a Večerni náladě z klavírních Letních dojmů, op. 22b, 1902). A konečně, Sukova největší koncertní vokálně-symfonická kompozice, Epilog, op. 37 (1920-33), obsahuje stručné úryvky ze Starého zákona a Žalmu 23. a text Ladislava Vycpálka podle závěrečné scény Zeyerovy legendy Pod jabloni.

Stanislav Pecháček si malé množství náboženských skladeb v Sukově hudbě vysvětluje tím, že Suk „svůj vztah $k$ Bohu a všemu nadpozemskému [...] žrejmě pocitoval jako ryze subjektivni záležitost a neměl potřebu dávat ji výraz ve své tvorbě, tím ji veřejně prezentovat a podílet se o ni s posluchači. "8 To však není přesné. Suk zjevně nepatřil mezi autory, kteří poslání své tvorby spatřovali ve službě náboženství, ale není pravda, že neměl potřebu umělecky vyjádřit svou konfesi. Po tragických událostech v rodině (smrti Antonína Dvořáka a své ženy Otilie) právě k vyjádření duchovní konfese směřoval, jak uvidíme. Podstatu věci je třeba hledat ještě v jiných faktorech.

Mše a duchovní kantáty byly často komponovány pro konkrétní bohoslužebný účel nebo na objednávku. Například Dvořák zkomponoval Mši D dur „Lužanskou“ k vysvěcení kaple v Lužanech a své velké kantáty a oratoria většinou pro hudební festivaly v Británii apod. U Suka se podobné účely nevyskytly, ostatně byl po většinu času zaměstnán koncertováním s Českým kvartetem, takže musel být značně vybíravý v tvưrčích plánech. A tam, kde mu šlo o nejvážnější vyjádření duchovní konfese, zjistíme výrazný rozdíl proti obvyklému katolickému pojetí - v Epilogu jej významně ovlivnilo též mystické vizionářství v dílech básníků Otokara Březiny a Julia Zeyera. Pecháčkova úvaha je zřejmě výstižná ve vztahu ke katolickému ritu jako praktické součásti lidového náboženského života. Jinak se věc měla se Sukovým osobním přemýšlením o otázkách života a smrti, které jej vedlo k neliturgickému vyjádření duchovní konfese.

A konečně, zatímco Antonín Dvořák, Josef Bohuslav Foerster či Ladislav Vycpálek byli značnou měrou autoři vokálního typu, Sukovou přirozeností bylo především vyjadřovat se instrumentálně. K vokální složce sahal jen ve zcela specifických intencích nebo z nutnosti, jediným ustálenějším vokálním druhem byly u něho cykly sborů, skoro vždy na texty lidových písní. Téměř zcela u něj schází písňová tvorba a úplně schází opera, což je mezi velkými českými skladateli té doby neobvyklé. Otakar Šourek v článku o Sukově písňové tvorbě, která čítá jen několik okrajových drobností, zmiňuje Sukovu osobní zkušenost s kompozicí vokální hudby. Suk se prý vyjádřil v tomto smyslu: „Nekomponuji na texty rád. Jako se cítím naprosto doma v živlu hudby instrumentální, tak si připadám nemotorným jako děcko, když mám psáti pro lidský hlas, zvláště když mě tísni při tom dojem, že mě slovo zdržuje v hudebnim myšleni. “9

Zdeněk Sádecký reflektuje věc z jiné stránky: Suk podle Sádeckého „nabyl tak výrazově nosné zvukové představivosti, že méně než Dvořák potřeboval sahat ke slovu, $k$ vokálním

8 PECHÁČEK, Stanislav. Česká sborová tvorba 1800-1950. Praha: Univerzita Karlova - Pedagogická fakulta, 2002, s. 248.

9 ŠOUREK, Otakar. Sukovy pisně. Tempo, 1934, roč. 14, č. 1, s. 6. 
druhưm a žánrům. "10 Důvodem této teze může být mj. skutečnost, že Sukova velká díla po Dvořákově smrti byla příznačná náměty s reflexivním obsahem (kterému se ještě budeme věnovat), ale Sukův způsob vyjádření se až na Epilog obešel bez zpívaného textu a i v Epilogu dominují úseky čistě instrumentální. V Pohádce léta Suk námět konkretizoval poetizujícími názvy vět a ke Zráni připojil část stejnojmenné básně Antonína Sovy jako motto, podstata uměleckého sdělení však zůstala v obou případech instrumentální.

\section{Hudební citace z náboženských skladeb}

Citací z náboženských skladeb není v Sukově tvorbě mnoho. Z chorálních melodií lze zmínit jen tradiční české chorály Ktož jsú boži bojovníci a Svatý Václave. Jinak Suk cituje z náboženské skladby pouze základní čtyřtónový motiv z Dvořákova Requiem.

Ohlas husitského chorálu Ktož jsú boži bojovníci je spatřován v hlavním tématu symfonické básně Praga, op. 26 (1904), a to kvůli charakteristickému rytmickému prvku a podobnosti začátku tématu s třetí frází chorálu. Avšak kromě toho, že nejde o dílo s náboženským námětem, údajný autorův výrok navíc zpochybňuje, že se vůbec jedná o záměrné odvození z tohoto chorálu - podle svědectví Bohumíra Štědroně Suk sice „ex post priznal názvuk, či lépe podobnost rytmu své symfonické básně Praga s uvedeným husitským chorálem, " ale s tím, že nešlo o úmyslný citát. ${ }^{11}$ Jednoznačné a vedle vlasteneckého určení i náboženské je naproti tomu užití chorálu Svatý Václave v jedné z nejhranějších Sukových komorních skladeb. Jde o Meditaci na staročeský chorál Svatý Václave, op. 35a, kterou Suk napsal roku 1914 jako protiváhu povinné rakouské hymny na koncertech Českého kvarteta za 1. světové války. Použil populární novější, tedy nikoli historický nápěv chorálu.

Emocionálně naléhavá skladba na obecně známý vlastenecký motiv byla pro České kvarteto za války ideálním prostředkem komunikace s českými posluchači, zvlášt̉ když je v ní dosti zdůrazněn motiv vztahující se ke slovům „pros za nás Boha, svatého Ducha“ a „nedej zahynouti nám ni budoucím“ (především v gradacích v taktech 26-32 a 57-66 a na konci vrcholu skladby v taktech 76-78). ${ }^{12}$ Přesto bylo ideové vyznění Meditace interpretováno různě. Část kritiky ji přijala jako upřímný výraz naděje národa za 1 . světové války. Ladislav Vycpálek napsal, že je to modlitba jednotlivce, se kterou se může posluchač ztotožnit, ale nikoli modlitba národa jako celku. ${ }^{13}$ Jiná část kritiky lpěla na tom, že skladba, která má vyjádřit národní naděje, má být bojovná, sebevědomá. Proto právě náboženský charakter Sukovy Meditace, tedy fakt, že jde o modlitbu, považovala za slabošský. Tento názor razili v Sukově době referenti Rektorysova časopisu Smetana - negativní

10 SÁDECKÝ, Zdeněk. Josef Suk. In Dějiny české hudebni kultury 1890/1945. I. 1890/1918. Praha: Academia, 1972, s. 153.

11 ŠTĚDROŇ, Bohumír. Lidová píseň v díle Josefa Suka. In Josef Suk: Život a dílo: Studie a vzpomínky. Jan Miroslav Květ (ed.). Praha: Hudební matice Umělecké besedy, 1935, s. 417-418.

12 SUK, Josef. Meditace na staročeský chorál „Svatý Václave“ pro smyčcové kvarteto [partitura]. Zdeněk Nouza (ed.). Praha: Editio Bärenreiter, 2016.

13 VYCPÁLEK, Ladislav. Nedělní koncerty České filharmonie. Hudební revue, 1915, roč. 8, č. 1, s. 36-37. 
recenze tehdy napsali Zdeněk Nejedlý ${ }^{14}$ a mladý Vladimír Helfert. ${ }^{15}$ Také Jiří Berkovec se v sukovské monografii z 50. let zmínil, že skladba sděluje ideu „nedej nám zahynouti“, místo aby sdělovala „nedejme sobě zahynouti“. Berkovec se zjevně musel na tomto místě (a několika dalších) podřídit tlaku tehdejší oficiální ideologie. Nicméně učinil tak obhajobou Sukovy Meditace - ve smyslu, že svým ryzím citem a nezlomným přesvědčením „pưsobi i dnes, kdy prece nepotřbujeme vzývat svatého Václava, ani koho jiného, aby nedal zahynouti nám ni budoucim. "16 Náboženský charakter této skladby vlastně reflektovali zpravidla ti, pro něž byl v pozitivním nebo negativním smyslu ožehavou otázkou - přitom původní určení díla bylo ryze praktické.

Citaci základního čtyřtónového motivu z Dvořákova Requiem použil Suk jednak ve Večerni náladě z klavírního cyklu Letni dojmy, op. 22b (1902), u které nelze žádný náboženský význam doložit. Motiv se tu objevuje v sousedství citace motivu ze Sukovy Písně lásky, op. 7 č. $1 .{ }^{17}$ Především však tento Dvořákův motiv, charakteristický svými půltónovými kroky, použil ve 2. a 3. větě symfonie Asrael, op. 27 (1906). Jak je obecně známo, jde o smuteční symfonii na pamět Antonína Dvořáka a jeho předčasně zesnulé dcery, Sukovy ženy Otilie. Důvod citace tedy může spočívat ve vzpomínce na autora Requiem i v křestanském poselství jeho díla. Konkrétní ideové popisy Asraela však máme z tehdejší doby k dispozici jen od vykladačů, kteří byli s autorem v blízkém přátelském kontaktu, především od Karla Hoffmeistera ${ }^{18}$ a Jana Miroslava Květa, ${ }^{19}$ nikoli od autora. Neexistuje psaný program, označení vět ani autorova dochovaná zmínka, které by specifikovaly poselství 2. a 3. věty v náboženském smyslu. Hoffmeister i Květ hovoří v souvislosti s těmito větami pouze o výrazu hrůzy a bolesti z osudu a smrti (bez náboženského kontextu). Oba však přisuzují spirituální charakter myšlenkovému vyústění celé symfonie. Podle Květa Suk dospěl v závěru 5. věty ke smíření, ve kterém nahlíží osud a smrt „sub specie aeternitatis “ a které umělecky reflektoval i později, zvláště v Epilogu. ${ }^{20}$ Sám autor v dopise Karlu Kovařovicovi roku 1907 odmítl vydání ideového popisu k opakování skladby, protože by se pisatel takového článku mohl minout jeho intencí a v Kovařovicovu provedení dílo „řekne zajisté vnímavým duším a ,lidem dobré vưle“ to, co říci chtělo. "21

14 NEJEDLÝ, Zdeněk. Josef Suka „Zrání“. Smetana, 1918, roč. 9, č. 1, s. 10.

15 HELFERT, Vladimír. Jos. Suk: Meditace na staročeský chorál „Svatý Václave“. Smetana, 1914, roč. 5, č. 1, s. 8 .

16 BERKOVEC, Jiří. Josef Suk (1874-1935): Život a dílo. Praha: Státní nakladatelství krásné literatury, hudby a umění, 1956, s. 148.

17 KVĚT, Jan Miroslav. Josef Suk: Život a dílo. In KVĚT (ed.), 1935, op. cit., s. 145-146.

18 HOFFMEISTER, Karel. Josefa Suka symfonie „Asrael“. Hudebni revue, 1908, roč. 1, č. 3, 4, 5, s. 149-152,

193-196, 259-262.

19 KVĚT, 1935, op. cit., s. 161-165.

20 Ibid., s. 164.

21 VOJTĚŠKOVÁ (ed.), 2005, op. cit., s. 69. 


\section{Křečovická mše}

Mši $B$ dur pro smíšený sbor, smyčce a varhany, která byla později nazvána Křečovická, zkomponoval Suk ještě jako chlapec před vstupem do kompoziční tř́ídy Karla Steckera, a sice bud'to na jaře roku 1889, nebo už v letních měsících roku 1888 (zdroje se liší). Ve své nezkušenosti nezhudebnil dvě věty z Creda, protože text opsal z nějaké mše z otcova notového archivu, kde náhodou chyběly.22 Jiří Berkovec vysvětluje toto dílo jako projev touhy „vyrovnat se hudebně se vzpomínkami na krásné zážitky z křečovického svatolukášského kưru, "23 jak na ně vzpomínal sám autor v projevu v Českých Budějovicích. ${ }^{24}$ Sukův životopisec a blízký př́tel Jan Miroslav Květ mezi podněty k této kompozici řadí dojmy mladého konzervatoristy z oper v Národním divadle v Praze, první zkušenosti s hrou $\mathrm{v}$ orchestru a dojmy ze života v prostředí kantorského rodu. ${ }^{25}$

Suk se na sklonku života rozhodl mši revidovat pro novodobou premiéru, a tak vytvořil roku 1931 novou verzi, kterou navíc zvolil pro první část koncertu na premiéře Epilogu v roce 1933. Z toho je zřejmý hluboký niterný vztah, který $\mathrm{k}$ této své juvenilii choval a ze kterého se vyznal v projevu v Českých Budějovicích, kde o ní a o Epilogu řekl: „v mé mysli obě dila splývaji près ten veliký časový odstup, protože jsou psána nadšeně, poctivě a pravdivě̀. “26 Své tvorbě tím vtiskl zajímavý vnitřní smysl - jeho životní dílo symbolicky otevírá i uzavírá umělecké vyjádření duchovního vyznání, na počátku tvorby dětsky bezprostřední, na konci tvorby zrcadlící na vrcholně náročné úrovni zkušenosti, kterými autor za celý život prošel. Podle Květa Suk rukopis mše rok co rok bral do ruky a v mysli se jí zaobíral, takže rozhodnutí pro úpravu do provozovatelného stavu nebylo nic překvapivého. ${ }^{27}$

Svou intenci při revizi charakterizoval v dopise koncertnímu pěvci a místopředsedovi sboru Besedy brněnské Stanislavu Tauberovi: „Rád jsem se občas podíval do neumělé partitury, v které bylo dost zdravých nápadi̊, a zajimaly mne vždy vlivy, které tenkrát na mne piosobily. Přdev̌̌ím vlivy starých, figurálek: Nyni opravuji partituru, ale jen tak, aby to odpovídalo mým zkušenostem, když mi bylo asi 18 let. Ty vlivy jsem zúmyslně ještě zdůraznil. Ale ještě pro něco jiného se tím obírám. Jest to vděčná vzpominka na otce a matku - jimž za vše děkuji, vzpominka na dètství. "28 Suk při revizi také přidal tympány; chybějící dvě věty z Creda nedoplnil, přidány byly teprve jeho žákem Juliem Kalašem pro užití při bohoslužbě, o kterém jsou vůbec záznamy teprve na základě dochovaných neautorských úprav, Sukovi samotnému šlo zřejmě jen o koncertní provedení; o možném provádění původní verze Sukovým otcem lze jen spekulovat, žádné záznamy se o něm nedochovaly. ${ }^{29}$

22 NOUZA - NOVÝ, 2005, op. cit., s. 10.

23 BERKOVEC, 1956, op. cit., s. 25.

24 KVĚT (ed.), 1946, op. cit., s. 110-111.

25 KVĚT, 1935, op. cit., s. 45.

26 KVĚT (ed.), 1946, op. cit., s. 118.

27 KVĚT, 1935, op. cit, s. 46.

28 VOJTĚŠKOVÁ, 2005, op. cit., s. 367.

29 NOUZA - NOVÝ, 2005, op. cit., s. 8, 11, 368, 370-371. 


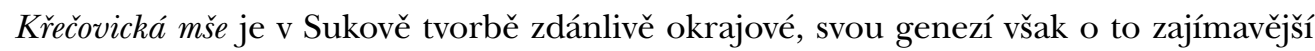
dílo. Zvláštnosti v hudebních myšlenkách vzniklé neškolenou dětskou invencí a směsí hudebních inspirací, legitimizace těchto myšlenek revizí po více než čtyřiceti letech, jejich směs se zkušenostmi zralého umělce, který se zároveň snažil vrátit se ke zkušenostem z doby svých zhruba osmnácti let, nostalgický podnět při revizi - to vše vytváří podmínky pro vznik díla svým zpo̊sobem unikátního. Jeho styl a porovnání obou verzí je na podrobnější samostatnou studii. Tak či onak pozadí vzniku Křčovické mše svědčí o tom, že ji lze jen těžko řadit mezi typické liturgické skladby vytvořené v ryze náboženské intenci. Spíše je ohlasem různých, samozřejmě i náboženských dojmů a inspirací začínajícího skladatele, toužícího ukázat své schopnosti, a její revize také více plodem nostalgického ohlédnutí než touhy podat tu výraz vlastní náboženské konfese nebo obohatit repertoár pro bohoslužebné účely.

\section{Pod jabloní}

K další hudební kompozici na náboženský námět přivedla Suka teprve roku 1901 objednávka hudby k dramatické legendě Julia Zeyera Pod jabloni. Ovšem když od Zeyera obdržel první část hry, byl to právě vypjatě religiózní charakter textu, co jej původně přivedlo k rozhodnutí spolupráci odmítnout. Stejný názor měl i hluboce nábožensky založený Dvořák. Když však Suk Zeyera s tímto úmyslem navštívil a nemocný Zeyer mu předčítal zbytek textu, Suk změnil názor: „Do soucitu se zhrouceným básnikem vstoupila představa jeho [Sukova] vlastniho rodinného štěstí, viděl v Živanovi a Danici symbol svého rodinného života - a jeho odhodláni Zeyerovi odřici rozplynulo se vniveč. "30 Premiéry v Národním divadle 28. prosince 1902 se Zeyer už nedožil.

Dílo obsahuje dvě náboženské scény pro smíšený sbor, které Suk zařadil do koncertní suity Pět obrazů z hudby k Zeyerově legendě Pod jabloní z roku 1911. Jde o obrazy z Nebe - Zpězy anděli̊ a Sbory blažených. Obraz se zpěvy andělů celou hru otevírá, do suity ho Suk kvůli logice hudební formy zařadil jako slavnostní finále. V jeho tehdejší tvorbě se podobné honosně nadpozemské scény jinak nevyskytují. Exaltovaný Zeyerův text byl Sukovi pro vokální zpracování poněkud danajským darem, zvláště pokud jde o závěrečný sbor prvního obrazu, ve kterém andělé vyprávějí o stvoření. Tato část Sukovy hudby se jeví až přetížená spojením mystického patosu, narativní sborové deklamace a Zeyerovy archaické mytické stylizace textu, který končí slavnostním provoláním: „Nás všecky a naši slávu Pán stvořil z vatry svaté!" Skladatel narativní charakter této části ztvárnil ilustrativními efekty ve vokální deklamaci textu i v instrumentální složce (varhany, sforzatissimo na disonantním tercdecimovém sedmizvuku orchestru mezi slovy „rozstup se, Tvore!“ a „zaduněl vesmir “ apod.) a vytvořil skutečně divadelní hudební scénu, která patrně na jeviště zapadá lépe než do koncertní suity. ${ }^{31}$ Podle Květa nalezl zalíbení ve scéně se sbory

30 KVĚT, Jan Miroslav. Ke vzniku některých Sukových skladeb: Julius Zeyer a Josef Suk. Tempo, 1934, roč. 13, č. 5, s. 152-153.

31 SUK, Josef. Pod jabloni op. 20: Dramatická legenda o šesti obrazech na slova Julia Zeyera: Klavirni výtah. Karel 
blažených, která jej inspirovala k poetickému kouzlu prosté slunné lyričnosti, která mu tehdy byla vlastní. ${ }^{32}$

Nadpozemská tematika Zeyerovy hry Suka inspirovala k některým barevným harmonickým postupům. Rozmnožování harmonických prostředků a orchestrální palety byl proces, který u něho probíhal celkově. I když v př́ípadě Zeyerových nebeských obrazů byl spojen s evokací mystičnosti, nelze říci, že by tehdy obecně souvisel s nějakým Sukovým př́́klonem ke spirituální oblasti. K tomu došlo až později, nejvíce v Epilogu. Sukův poměr k Zeyerově látce v době práce na scénické hudbě je třeba chápat v kontextu jeho tehdejšího myšlenkového světa, který se od Zeyerova odlišoval. Suk byl mladý umělec, prožívající svá nejštastnější léta v osobním i uměleckém životě, pro kterého pohádková láska Zeyerova Radúze a Mahuleny mimoděk vystihovala jeho pocity. Není tedy divu, že pro hudbu k legendě Pod jabloni jsou nejvíce charakteristické ty rysy, které jsou blízké poetice Radúze a Mahuleny - secesní pohádkovost, praslovanské mytické ovzduší, prostá láska mladých hrdinů, bezprostřední srdečnost ztvárnění dobra bojujícího se zlem. To vše je vyjádřeno široce tekoucí bohatou melodikou a velmi barevnou zvukovostí, čerpanou zvláště z nevšední invence $\mathrm{v}$ instrumentaci, která je u legendy odstíněná ještě jemněji než v Radúzovi a Mahuleně.

Pohádkovost poetiky a motivů dobra a lásky v obou Zeyerových hrách bylo tedy pole, na kterém se oba umělci ideálně sešli. V legendě Pod jabloni bylo však spojeno s tou Zeyerovou stránkou, která byla tehdy Sukovi vzdálenější - s náboženskými vizemi. Náboženská mystéria a hledání duchovní konfese jsou témata Zeyerovy tvorby v celém jejím průřezu. Jsou od počátku spojena s jeho zpracováním mýtů, historických a exotických námětů, bájí a legend, které přetvářel estetizační činností v „obnovené obrazy“. Toto hledání má u něho podobu sporů různých koncepcí (křestanství, buddhismu apod.) a v jeho pozdním období vede k příklonu ke katolictví, zvláště však k niternému sepětí s Kristem jako principu žité víry, která je protikladná k normativní formě náboženství. ${ }^{33}$ Jan Vorel hovoří u Zeyera o motivu „pouti“, ve které lze rozpoznat „hlubinnou symboliku překročeni skutečnosti (transcendence) a poznáni nadsmyslové pravdy. "34 Tuto pout analyzuje na prŕíkladu Zeyerových próz a charakterizuje ji jako útěk do „vnitřního exilu“, v němž se zrcadlí autorův „prožitek osobni deziluze, pocity vykořeněni a citové krize, jdoucí ruku v ruce s touhou po vymaněni se z pout bezcilně pohybujicího se světového prostoru, prožitek vypovídajicí o zoufalém hledáni věčných pravd ztracených neznámo kde." Zeyerovi hrdinové procházejí „duchovní tmou“ a „labyrintem světa“, aby našli ve vnějším i vnitřním exilu poznání tajemství a skrytých pravd. ${ }^{35} \mathrm{~V}$ exaltovaných vizích Nebe a andělů v legendě Pod jabloní se již také nabízí souvislost s životní situací nemocného tvůrce, který tušil blízkost smrti, situací zcela protichůdnou k Sukově.

Šolc (ed.). Praha: Hudební matice Umělecké besedy, 1945.

32 KVĚT, 1934, op. cit., s. 154.

33 SLÁDEK, Ondřej. Náboženský kaleidoskop Julia Zeyera. In Julius Zeyer, lumírovský básnik v duchovním děni Evropy. Michal Fránek et. al. (eds.). Brno: Host, 2009, s. 40-51.

34 VOREL, Jan. „Cesty“Julia Zeyera do ,jiných světů“. In FRÁNEK et al. (eds.), 2009, op. cit., s. 110.

35 Ibid., s. 111-112. 
Suk se přesto nadpozemským rozměrem legendy Pod jabloni inspiroval i v ideové oblasti, avšak až v pozdějším období své tvorby - pro závěrečnou vokální část Epilogu.

\section{Duchovní reflexe v Sukově podvořákovské tvorbě}

Tragické události v Sukově rodině - smrt Antonína Dvořáka a Sukovy ženy Otilie o rok později - způsobily v jeho tvorbě zřetelný zlom, i když lze říci s Václavem Štěpánem, že přece jen připravovaný. ${ }^{36}$ Skladatel náhle začal zcela zásadně reflektovat téma smrti, které se u něho sice již několikrát objevilo, ale pouze zprostředkovaně přes určité literární látky (Radúz a Mahulena a několik sborů na texty lidových písní). Sám autor v dopise Otakaru Šourkovi charakterizoval svou podvořákovskou tvorbu jako niternou cestu z bolesti, osudu a smrti ke světlu, které si musí vybojovat a stále více se mu přibližovat. „Po oklikách a dlouhé cestě byl bych se jistě naučil, co mě naučil Osud náhle, že dílo má tehdy oprávněnost, když tvůrce může přesvědčivě podati útěchu trpicim, a že to může jen tehdy, když zakusi sám velikou bolest a $v$ ni se očisti." 37

Na spirituální rozměr Asraela, o kterém už byla řeč, navazuje Sukův nápad zhudebnit myšlenku z 23. žalmu: „Byt’ se mi dostalo jíti přes údoli stínu smrti, nebudu se báti zlého, nebot’ Ty se mnou jsi. "Roku 1907 načrtl smíšený sbor a capella Hospodin jest můj pastýr, který však škrtl a dále nepoužil. ${ }^{38}$ Podle Květa se již tehdy rozhodl tuto myšlenku zpracovat v rozsáhlejším díle, kterému se chtěl věnovat později (tímto dílem se stal Epilog). ${ }^{39}$ Hudební materiál skici Hospodin jest mi̊j pastýr není v Epilogu použit a stylově souzní s okruhem Sukovy tvorby kolem roku 1900 - Radúze a Mahuleny i Asraela. Trojí či čtveré opakování akordu v rámci jednoho taktu či na jednom slově na konci fráze („nedostatku“ apod.) upomíná na smíšený sbor Ó mladosti z hudby k Radúzovi a Mahuleněe, ${ }^{40}$ jehož melodii Suk použil jako vedlejší téma Smutečni hudby v suitě Pohádka. Toto charakteristické opakování používal tehdy s oblibou (viz také Vratkův popěvek z téže scénické hudby). Sestup po kvintách a kvartách od slov „byt’ se mi“ po slovo „smrti“ vzdáleně upomíná na sestup ve sboru $O ́$ mladosti na slovech „,kam brzy dopadneš“.

Ono rozsáhlejší dílo na námět 23. žalmu Suk začal koncipovat teprve roku 1920. Mezitím ušel významný kus tvůrčí cesty přes dvě velká symfonická díla - pětivětou Pohádku léta, op. 29 (1907-09) a symfonickou báseň Zrání, op. 34 (1912-17). Svými náměty, které Suk stručně vyložil v projevu v Českých Budějovicích, zapadají do jeho výše zmíněného výkladu o „cestě ke světlu“: Pohádka léta jako vyprávění o nalézání nové duševní síly v náruči přírody, Zráni jako niterná autobiografie, v níž autor nalézá cestu ke světlu v boji

36 ŠTĚPÁN, Václav. Novák a Suk. Praha: Hudební matice Umělecké besedy, 1945, s. 12-13.

37 VOJTĚŠKOVÁ (ed.), 2005, op. cit., s. 220-221.

38 Tato př̌škrtnutá skica je uložena ve fondu Městského muzea Sedlčany pod inventárním číslem Su 73.

39 KVĚT, 1935, op. cit., s. 164-165.

40 SUK, Josef. Radúz a Mahulena: Hudba k pohádce Julia Zeyera: Klavírni výtah [zpracoval Roman Veselý]. Praha: Státní nakladatelství krásné literatury, hudby a umění, 1955, s. 52-55. 


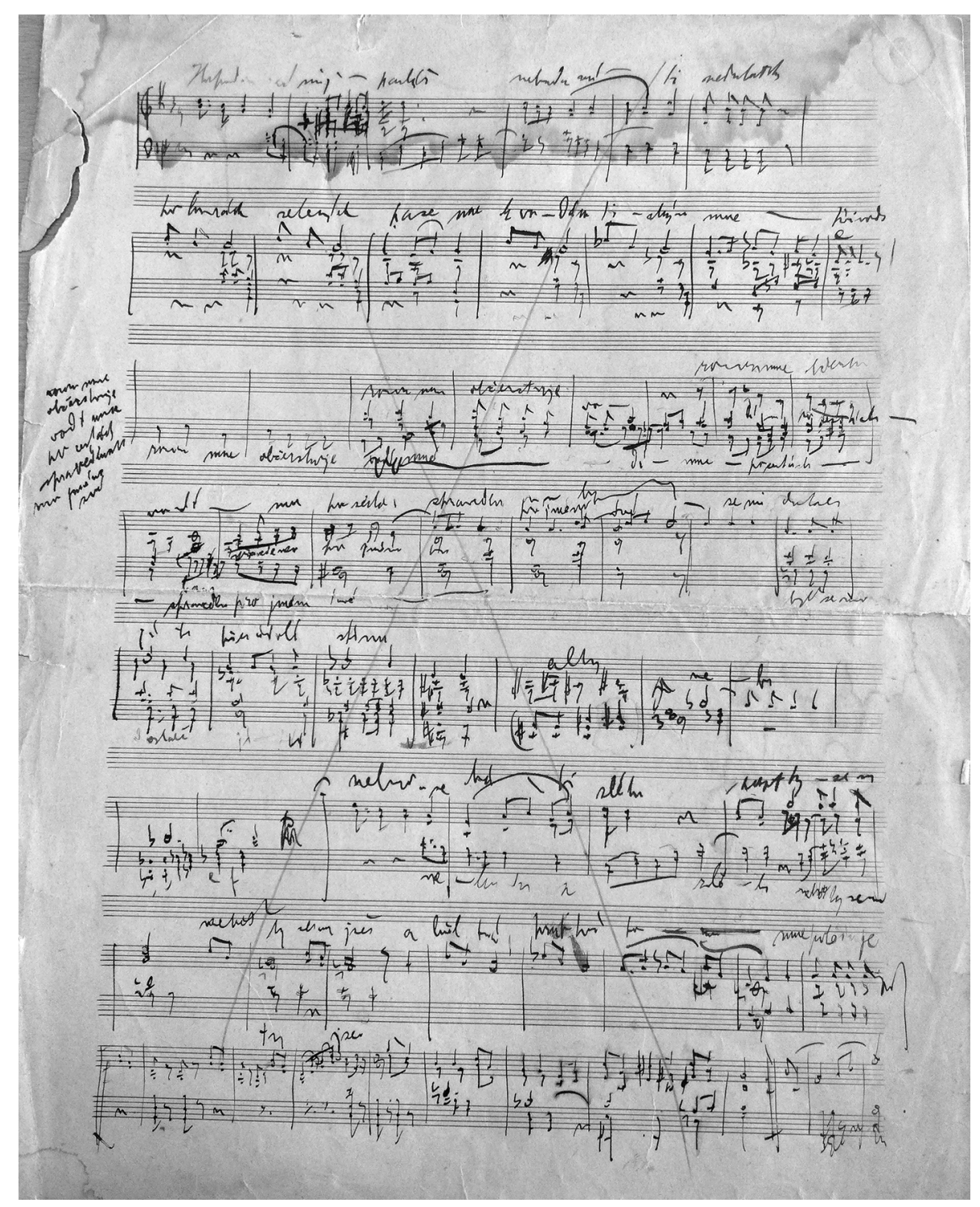

Obr. 1 Autograf nedokončené skici sboru Hospodin jest můj pastýř. Zdroj: Městské muzeum Sedlčany, inv. č. Su 73.

za životní klad, v nezdolné vůli a práci. ${ }^{41}$ Na ně pak navazuje jako závěr velkého symfonického cyklu Epilog, op. 37, skladba pro sólový soprán, baryton, bas, velký a malý smíšený sbor a orchestr, komponovaná v letech $1920-29$ a ve své definitivní verzi dokončená roku 1933.

41 KVĚT (ed.), 1946, op. cit., s. 117-118. 
V první části skladby zpívá bas slova žalmu, pozměněná na otázku: „Až se mně dostane jíti pres údolí stínu smrti, nebudu se báti zlého?" Způsob zhudebnění je zcela jiný než v nedokončeném sboru - ve zlověstném pochodovém rytmu kontrastuje sestupná septima s následujícími tonálně labilními půltónovými postupy. ${ }^{42}$ Po chvíli se ozvou ve smíšeném sboru s výrazem zděšení biblická slova: „Prach jsi a v prach se obrátǐ̌!" Další otextovaný úsek je až poslední část díla, podobenství podle závěrečné scény legendy Pod jabloni. K lidem přichází unavený poutník (baryton) a prosí o jídlo a pití. Podávají mu kalnou vodu a černý chléb a omlouvají se, že nic lepšího nemají, ale poutník odpovídá: „Když s láskou podán, jak moh by hořknout dar?" Chléb se náhle promění a z vody se stane mléko. Lidé užasnou a vzývají zázračnou moc poutníka, ale on říká: „Jen pro vaši lásku divy se staly, pro vaši lásku jen. Chléb lámu s vámi, duch věčné lásky nad vámi se vznáši." Po hymnickém vrcholu smíšeného sboru, který zpívá o „dobrém klasu“, rostoucím „z dobrého nitra v žeň lásky“, a o duchu věčné lásky, který ,je v nás a nad námi se vznáší“, následují závěrečná slova: „Až se mi dostane jíti pres údoli stínu smrti, nebudu se báti zlého, protože ty se mnou jsi. Duch věčné lásky nad námi se vznáší, lásky duch věčný, duch lásky věčné, věčný duch lásky. "

Toto zvláštní spojení motivů legendy Pod jabloni se slovy 23. žalmu způsobuje víceznačnost vyznění, pokud jde o vztah díla k náboženské víre. Podle Jaroslava Smolky závěrečná odpověd’ není vyznáním víry v Boha a pozměňuje tak náboženský smysl biblického citátu. ${ }^{43}$ Bohumír Štědroň naopak s poukazem na Sukův dopis Kristě Stejskalové ${ }^{44}$ vykládá smysl Epilogu právě jako vyznání křestanské víry. ${ }^{45}$ Náboženskému smyslu nasvědčuje i dopis Ladislavu Vycpálkovi (autorovi úpravy textu z legendy Pod jabloni) z 18. dubna 1933. Suk v něm vypráví, jak jej na Bílou sobotu zpěv lidu o vzkřríšení Krista přivedl ke vzpomínce na otce: „Bylo mi do pláče a do modlitby. Více než kdy cítil jsem, že jen Kristova ruka může ukazovat cestu. " ${ }^{\text {"46 }}$ Rovněž autorův vlastní výklad smyslu díla svědčí o transcendentálním, nikoli jen morálním rozměru poselství: „Neni smrti, to, oč usilujeme, o to usiluje a bude usilovati lidstvi od věčnosti až do věčnosti. Beze smrti nemohl by povstati život nový a věčný, a proto dle slov Písma: ,Smrti, kde hrot tvưjj, kde osten tvioj? “47 Nicméně zůstává tu podstatný rozdíl od tradičního křestanského pojetí, vyjádřeného např. ve Vycpálkově kantátě České rekviem - Smrt a spasení. V Epilogu to není Spasitel, na co je položen důraz. Obrazem Krista není ani onen poutník, kterého Suk přirovnal k moudrému stařečkovi z Čapkova Krakatitu. ${ }^{48}$ O Kristu se tu vůbec nehovoří a v textu nikde není slovo „Bůh“, nýbrž jen víceznačný pojem „duch věčné lásky“. Principem katarze je tu samotná altruistická láska bez specifického nábožensky konfesijního kontextu.

42 SUK, Josef. Epilog [partitura]. Otakar Šourek (ed.). Praha: Hudební matice Umělecké besedy, 1939, s. 1720 .

43 SMOLKA, Jaroslav. Hudba v prvni Československé republice. Praha: Akademie múzických umění, Hudební fakulta, 1999, s. 43.

44 VOJTĚŠKOVÁ (ed.), 2005, op. cit., s. 306.

45 ŠTĚDROŇ, Bohumír. Sukưv Epilog: Josef Suk o své skladbě a víre v Boha. Lidové noviny, Brno, 14. 5. 1939, s. 5 .

46 VOJTĚŠKOVÁ (ed.), 2005, op. cit., s. 381.

47 KVĚT (ed.), 1946, op. cit., s. 118.

48 VOJTĚŠKOVÁ (ed.), 2005, op. cit., s. 316. 
Suk tu slova žalmu a scénu ze Zeyerovy legendy nejen propojil, ale oboje i reinterpretoval, protože Zeyer nezdůrazňuje lásku svých hrdinů v kontextu smrti a věčnosti, nýbrž pokory a nezištnosti. Jde u něho o vizi spravedlivého světa bez ziskuchtivosti a závisti, o kterém Živan v posledním obrazu sní. Suk se pokusil vyjádřit ideu všelidské lásky, podobnou březinovské vizi spojených rukou obepínajících svět, a v ní nalézt konečnou odpověd' na otázku smrtelnosti. Miloš Bezděk podal přímé svědectví, že právě Otokar Březina, kterého Suk velice obdivoval, inspiroval Epilog. Suk si koncem roku 1918 chtěl nechat od Březiny napsat text pro skladbu a Březina mu vyhověl nepř́imo - svými typickými vizionářskými metaforami podal nástin ideové látky, který Suk s vděčností přijal jako hlubokou a krásnou inspiraci. ${ }^{49} \mathrm{~V}$ tomto Březinově dopise nalezneme např́klad slova: „opojeni ze síly všech bratrských milionů rukou, spojených tajemně, osvobozujicích člověka na zemi. "50 $\mathrm{Na}$ Bezděkův návrh Suk připojil ke skladbě i závěr Březinovy básně Mýtus ženy jako motto. ${ }^{51}$ I program neotextovaných částí skladby, který popsal Suk Květovi pro uveřejnění v Tempu, svědčí o inspiraci Březinou: motiv matek jako nositelek nejčistší pozemské lásky (malý ženský sbor beze slov), obraz věčného duchovního zápasu člověka, motiv proroků, tajemný úžas nad tajemstvím existence apod ${ }^{52}$ Celý obsah je podán velmi složitým a expresivním, interpretačně i percepčně obtížným hudebním jazykem, kterým dospěl Sukův stylový vývoj k vrcholu.

Suka také inspirovala idea sbratření lidí z Ódy na radost, pro kterou si Beethovenova díla vážil jako nositele nejvyššího mravního poselství. ${ }^{53}$ At̉ už ve vyznění Epilogu budeme, či nebudeme spatřovat specifický náboženský smysl - protože toto dílo vlastně umožňuje posluchači oba př́ístupy - zůstává jeho poselstvím nesporně to, o čem Suk hovořil ve svém projevu o Beethovenově tvorbě: „evangelium lidstvi“. ${ }^{54}$

\section{Závěr}

Na počátku Sukova životního díla stála latinská mše, která symbolizuje tradiční duchovní kořeny v kantorské rodině, z nichž Suk vyrůstal. Nicméně svým tvưrčím poměrem k náboženské tematice se nakonec zařadil mezi autory, u kterých už nejsou duchovní látky vyčleněny do svých tradičních druhů - mší, duchovních kantát, oratorií apod. - a stávají se součástí symfonické tvorby. V Sukovu zpo̊sobu vyjádření tak hrálo podstatnou roli programní symfonické myšlení, byt v Epilogu významně doplněné textem. Hlavním impulzem cesty $\mathrm{k}$ duchovní reflexi byly tragické události v jeho rodině, zvláště předčasná smrt manželky. Nebyl to sice impulz, který by plynul z nějaké dekadentní reflexe světa,

49 BEZDĚK, Miloš. Josef Suk a Otokar Březina. In KVĚT (ed.), 1935, op. cit., s. 442-443. Viz též BEZDĚK, Miloš. Otokar Březina a „Epilog“Josefa Suka. Tempo, 1934, roč. 13, č. 5, s. 168-170.

50 BEZDĚK, 1935, op. cit., s. 443.

51 Ibid., s. 449.

52 KVĚT, Jan Miroslav. Epilog, vrcholné dílo Josefa Suka. Tempo, 1933, roč. 13, č. 4, s. 97-104.

53 KVĚT (ed.), 1946, op. cit., s. 33.

54 Ibid., s. 27. 
jak bylo pro tehdejší umění příznačné (nálady „fin de siècle“, negace světa, pocit odcizení apod.), ale vedl jej k dílům mezioborově typickým pro umění doby secese, v němž se jeho umělecký typ formoval. Historické pozadí Epilogu - byt k vlastní kompozici došlo až ve 20. letech - je tvořeno symbolismem, dobovou oblibou teozofie a duchovních filozofií nejrůznějšího druhu, vokálními symfoniemi Gustava Mahlera, duchovním vizionářstvím Julia Zeyera a Otokara Březiny apod., obecně hledáním cesty z krize doby, která podnítila řadu směrů tzv. moderny. Je to situace již odlišná od tvůrčího poměru, který k náboženské oblasti choval Antonín Dvořák. Reflexe, ve kterou Sukovo životní dílo vyústilo, měla vysloveně subjektivní podstatu - zrodila se z osobního prožitku zranění citových hodnot, které podnítilo potřebu revize duchovních základů vlastního života, potřebu jejich hlubšího pochopení a vyjádření individuální uměleckou formou. K důsledkům této intence patří i vysoká obtížnost Sukova pozdního stylu.

\section{Bibliography}

BERKOVEC, Jiří. Josef Suk (1874-1935): Život a dílo. Praha: Státní nakladatelství krásné literatury, hudby a umění, 1956.

BEZDĚK, Miloš. Otokar Březina a „Epilog“ Josefa Suka. Tempo, 1934, roč. 13, č. 5, s. 168-170.

Dějiny české hudebni kultury 1890/1945. I. 1890/1918. Praha: Academia, 1972.

FRÁNEK, Michal et. al. (eds.). Julius Zeyer, lumírouský básnik v duchovním děni Europy. Brno: Host, 2009.

HELFERT, Vladimír. Jos. Suk: Meditace na staročeský chorál „Svatý Václave“. Smetana, 1914, roč. 5 , č. 1 , s. 8.

HOFFMEISTER, Karel. Josefa Suka symfonie „Asrael“. Hudebni revue, 1908, roč. 1, č. 3, 4, 5, s. 149-152, 193-196, 259-262.

KVĚT, Jan Miroslav. Epilog, vrcholné dílo Josefa Suka. Tempo, 1933, roč. 13, č. 4, s. 97-104.

KVĚT, Jan Miroslav. Ke vzniku některých Sukových skladeb: Julius Zeyer a Josef Suk. Tempo, 1934, roč. 13 , č. 5, s. 152-153.

KVĚT, Jan Miroslav (ed.). Josef Suk: Život a dílo: Studie a vzpominky. Praha: Hudební matice Umělecké besedy, 1935.

KVĚT, Jan Miroslav (ed.). Živá slova Josefa Suka. Praha: Topičova edice, 1946.

Městské muzeum Sedlčany, inv. č. Su 73, Josef Suk: Hospodin jest můj pastýř - autograf skici.

NEJEDLÝ, Zdeněk. Josef Suka „Zrání“. Smetana, 1918, roč. 9, č. 1, s. 10.

NOUZA, Zdeněk - NOVÝ, Miroslav. Josef Suk: Tematický katalog skladeb. Praha: Editio Bärenreiter, 2005.

PECHÁČEK, Stanislav. Česká sborová tvorba 1800-1950. Praha: Univerzita Karlova - Pedagogická fakulta, 2002.

SMOLKA, Jaroslav. Hudba v proni Československé republice. Praha: Akademie múzických umění, Hudební fakulta, 1999.

SUK, Josef. Epilog [partitura]. Otakar Šourek (ed.). Praha: Hudební matice Umělecké besedy, 1939.

SUK, Josef. Pod jabloní op. 20: Dramatická legenda o šesti obrazech na slova Julia Zeyera: Klavírní výtah. Karel Šolc (ed.). Praha: Hudební matice Umělecké besedy, 1945. 
SUK, Josef. Radúz a Mahulena: Hudba k pohádce Julia Zeyera: Klavirni výtah [zpracoval Roman Veselý]. Praha: Státní nakladatelství krásné literatury, hudby a umění, 1955.

SUK, Josef. Meditace na staročeský chorál „Svatý Václave“ pro smyčcové kvarteto [partitura]. Zdeněk Nouza (ed.). Praha: Editio Bärenreiter, 2016.

SVOBODOVÁ, Marie (ed.). Josef Suk: Dopisy nejbližšim. Praha: Supraphon, 1976.

ŠACH, Josef. Josef Suk: Vzpomínková mosaika. Praha: A. Neubert, 1941.

ŠOUREK, Otakar. Sukovy pisně. Tempo, 1934, roč. 14, č. 1, s. 6.

ŠTĚDROŇ, Bohumír. Sukův Epilog: Josef Suk o své skladbě a víre v Boha. Lidové noviny, Brno, 14. 5. 1939, s. 5.

ŠTĚPÁN, Václav. Novák a Suk. Praha: Hudební matice Umělecké besedy, 1945.

VOJTĚŠKOVÁ, Jana (ed.). Josef Suk: Dopisy o životě hudebním i lidském. Praha: Editio Bärenreiter, 2005.

VYCPÁLEK, Ladislav. Nedělní koncerty České filharmonie. Hudebni revue, 1915, roč. 8, č. 1, s. 36-37. 